\title{
STATUS QUO OF GENDER EQUALITY IN EU RURAL BUSINESS MANAGEMENT
}

\author{
Lesya Kolinets', Volodymyr Tokar ${ }^{2 *}$ \\ ${ }^{1}$ Dr. habil Ternopil National Economic University, 11 Lvivska Str., Ternopil, Ukraine, 46009, \\ Phone+380677538663.E-mail: kolinets@i.ua \\ ${ }^{2}$ Prof. Dr. habil Kyiv National Economic University named after Vadym Hetman. \\ 54/1 Peremohy Avenue, Kyiv, Ukraine, 03057, Phone+380983805107.E-mail: tokarww@ukr.net
}

Received 1907 2019; Accepted 02092019

The relevance of article relates to achieving sustainable development goals declared by the United Nations Organization and enrooted in the EU legislature and practice, namely guaranteeing gender equality and eradicating hunger via enhancing agricultural production. The main research problem is determining the status quo of gender equality in EU rural business management. The purpose of the article is to estimate the female-to-male ratio among managers of agricultural holdings in EU member-states. The goals of the article include determining leading countries and outsiders, as well as suggesting recommendations to change the situation. The research methodology relies on converting the raw data to ratios, truncating the data at equality benchmark and ranking. This approach can be used for evaluating and monitoring the efficiency of measures aimed at fostering gender equality in the EU rural business in the future. The results showed the leading positions of Baltic countires, probably, due to their openness to new innovative ideas of female empowerment, especially after freeing from the communist burden, and lack of traditional managerial structure determining the patterns in other EU member-states (i.e., Germany, Denmark, and Netherlands). Special measures devoted to overcoming the discovered absence of gender parity should include information campaigns advertising managerial positions in agriculture for females, gender quotas, training programs and mentorship aimed at bridging the gender gap in rural business management.

Key words: agricultural managers, gender equality, rural business, sustainable development goals, EU member-states.

JEL Codes: J16, Q13.

* Coresponding Author

Copyright (C) 2019 The Authors. Published by Vytautas Magnus University. This is an open-access article distributed under the terms of the Creative Commons Attribution-NonCommercial 4.0 (CC BY-NC 4.0) license, which permits unrestricted use, distribution, and reproduction in any medium, provided the original author and source are credited. The material cannot be used for commercial purposes. 


\section{Introduction}

During the first quarter of the $21^{\text {st }}$ century, in spite of prodigious achievements of the global scientific and technological, as well as innovation development in solving the global problems of humankind, the world community still faces the challenges of the global food problem. In spite of 2 percent annual growth of the global production of foodstuffs and 1.14 percent increase in the world population (Holt-Gimenez, 2008), over 850 million people do not have the access to the volume of foodstuffs sufficient for active and healthy life (Lukianenko, 2014). Agriculture is one of the key food production sectors aiming at solving the global food problem. The efficiency of rural business depends on the set of different factors, including the equality between men and women both working and managing agricultural holdings.

Agarwal highlights the role of gender equality (UN Sustainable Development Goal - SDG 5) in implementing other SDG goals, including eradicating poverty (SDG 1) and hunger (SDG 2) (Agarwal, 2018). Johnson et. al supported the idea that female ownership of assets reduces the poverty in rural areas via positive effects on outcome at the household and individual levels (Johnson, 2016). Theriault, Smale, and Haider discovered that eliminating the male bias in extension services and improving access to financing and equipment to female plot managers foster the sustainable agriculture (Theriault, 2017). Osabuohiena et. al. showed that even though large-scale agricultural land investments increased productivity, created new jobs and facilitated rural development, there is still a need for targeting of potential beneficiaries to ensure the rural female empowerment in Africa (Osabouhiena, 2019). Drucza and Peveri shed light on ignoring the female sector of the small farming household and the role of labor investment by women in livestock in Pakistan due to traditional bias (Drucza, 2018). Palacios-Lopez, Christiaensen, and Kilic argued that investments in raising agricultural female labor productivity provide high returns in reaching female empowerment and improving nutrition of children in Africa (Palacios-Lopez, 2017). Zirham and Palomba proved the existence of a link between females managing farms in the short food supply chain and the innovative boom in Italian agriculture (Zirham, 2016).

Mekonnen, Gerber, and Matz substantiated the role of networks of female household members in promoting agricultural innovations and yield improvement in the case of row-planting (Mekonnen, 2018). Mutenje et. al. demonstrated that women's bargaining power and access to information positively influenced the probability of investing in climate smart agriculture technologies (Mutenje, 2019). Campos, Covarrubias, and Patron found that "older status of female heads, holders and manager of plots, child dependency ratio, and limited access to adult male labor are factors decreasing productivity in female plots in Uganda" (Campos, 2016). Alkire et al. shed light on the Women's Empowerment in Agriculture Index, which consists of two subindices covering decisions about agricultural production, productive resources, use of income, community leadership, and time allocation, as well as measuring the percentage of women whose achievements are at least as high as men in their households (Alkire, 2013). Using Women Empowerment in Agriculture Index in Ghana, Ragsdale et al. found that women lack empowerment in input in productive 
decision-making, purchase, sale, or transfer of assets, and speaking in public raising the topicality of special programs devoted to achieving gender equity in rural business (Ragsdale, 2018).

Akter et al. (2017) disclosed that female empowerment being the pre-condition for achieving the global food security requires country-specific interventions aimed at closing the gender gaps in agriculture (Akter, 2017), while Sraboni and Quisumbing (2018) showed the interplay between women's empowerment in agriculture and improvement of dietary quality of individuals within households in Bangladesh (Sraboni, 2018). Fischer et al. suggested gender-sensitive training and the establishment of group models to promote the forage chopper's sustainability in Tanzania (Fischer, 2018). Doss et. al. declared the necessity to improve gender statistics on land tenure, control over assets, and work burden, including chores aimed at monitoring the impact of programs and policies, as well as enabling the identification of drivers of positive changes (Doss, 2018). Johnson and Schnakenberg stated that amendment of civic agriculture requires the empowerment of female farmers via gendered organizations, horizontal networks, and innovative strategies (Johnson, 2017). Therefore, there is a bulk of literature proving the efficiency of gender equity in agriculture, but the above-mentioned researches concentrating on many different aspects lack the specific emphasis on the European situation. Therefore, in our paper, the main research problem is determining the status quo of gender equality in EU rural business management. The purpose of the article is to estimate the female-to-male ratio among managers of agricultural holdings in EU member-states. The goals of the article include determining leading countries and outsiders, as well as suggesting recommendations to change the situation.

\section{Research methodology}

By analogy with the Global Gender Gap Index, introduced by World Economic Forum in 2006, we determine the gender equality in rural business management of EU member-states, namely gender parity from 0 (total inequality) to 1 (equality) (World, 2019). We concentrate on estimating gaps, capture outcome variables and rank on gender equality.In our study, we shed light on female-to-male ratios among managers considering number of farms, agricultural area, and labor force. The process of evaluating the gender gap embraces converting the raw data retrieved from Eurostat to ratios, truncating the data at equality benchmark (namely, the equality in quantity of females and males engages in rural management) and ranking EU member-states.

Using the Eurostat statistics (Eurostat, 2019) on number of farms, agricultural area, and labor force by age and sex of the manager in 2005, 2010, and 2013 (the latest available data), we calculate the female-to-male ratios and estimate the status quo for the EU member-states determining maximum, minimum, and average values for each country and for the sample itself. Finally, we determine the changes in scores and rank EU member-states based on their results. 


\section{Research Results and Discussion}

Table 1 shows that the best scores of female-to-male ratios of managers considering number of agricultural holdings under supervision in EU member-states in 2005-2013 featured the Baltic countries, namely Lithuania (0.890 in 2013), Latvia (0.823), and Estonia (0.534). The worst ones were Malta, Germany, Netherlands, and Denmark. The average value of this indicator increased from 0.298 in 2005 to 0.305 in 2013, as well as well as median (from 0.243 to 0.274 ) and maximum (from 0.882 to 0.890 ), while minimum value slightly decreased from 0.072 to 0.063 .

Table 1. Dynamics of female-to-male ratio of managers considering number of agricultural holdings under supervision in EU member-states in 2005-2013

\begin{tabular}{|c|c|c|c|c|c|c|c|}
\hline \multirow{3}{*}{ Country } & \multirow{2}{*}{\multicolumn{2}{|c|}{2005}} & \multirow{2}{*}{\multicolumn{2}{|c|}{2010}} & \multirow{2}{*}{\multicolumn{2}{|c|}{2013}} & \multirow{3}{*}{ Change } \\
\hline & & & & & & & \\
\hline & Score & Rank & Score & Rank & Score & Rank & \\
\hline Lithuania & 0.739 & 2 & 0.912 & 1 & 0.890 & 1 & 0.151 \\
\hline Latvia & 0.882 & 1 & 0.879 & 2 & 0.823 & 2 & -0.058 \\
\hline Estonia & 0.587 & 3 & 0.558 & 3 & 0.534 & 3 & -0.053 \\
\hline Austria & 0.518 & 4 & 0.526 & 4 & 0.491 & 4 & -0.027 \\
\hline Romania & 0.407 & 6 & 0.478 & 5 & 0.488 & 5 & 0.081 \\
\hline Poland & 0.470 & 5 & 0.423 & 7 & 0.432 & 6 & -0.037 \\
\hline Italy & 0.388 & 7 & 0.443 & 6 & 0.418 & 7 & 0.031 \\
\hline Portugal & 0.325 & 10 & 0.414 & 8 & 0.405 & 8 & 0.080 \\
\hline Hungary & 0.310 & 11 & 0.357 & 11 & 0.364 & 9 & 0.054 \\
\hline Greece & 0.337 & 9 & 0.383 & 9 & 0.356 & 10 & 0.019 \\
\hline Slovenia & 0.355 & 8 & 0.375 & 10 & 0.295 & 11 & -0.060 \\
\hline Bulgaria & 0.215 & 17 & 0.295 & 12 & 0.288 & 12 & 0.074 \\
\hline Spain & 0.235 & 15 & 0.276 & 15 & 0.286 & 13 & 0.052 \\
\hline France & 0.274 & 12 & 0.294 & 13 & 0.274 & 14 & -0.001 \\
\hline Cyprus & 0.271 & 13 & 0.260 & 16 & 0.241 & 15 & -0.030 \\
\hline Luxembourg & 0.145 & 20 & 0.189 & 18 & 0.202 & 16 & 0.057 \\
\hline Slovakia & 0.243 & 14 & 0.206 & 17 & 0.190 & 17 & -0.054 \\
\hline Belgium & 0.177 & 19 & 0.177 & 21 & 0.180 & 18 & 0.003 \\
\hline Sweden & 0.129 & 22 & 0.182 & 19 & 0.179 & 19 & 0.051 \\
\hline United Kingdom & 0.220 & 16 & 0.150 & 22 & 0.175 & 20 & -0.045 \\
\hline Czech Republic & 0.201 & 18 & 0.178 & 20 & 0.134 & 21 & -0.067 \\
\hline Ireland & 0.129 & 21 & 0.130 & 23 & 0.123 & 22 & -0.006 \\
\hline Finland & 0.117 & 24 & 0.125 & 24 & 0.106 & 23 & -0.010 \\
\hline Malta & 0.089 & 26 & 0.125 & 25 & 0.102 & 24 & 0.013 \\
\hline Germany & 0.094 & 25 & 0.092 & 27 & 0.094 & 25 & 0.000 \\
\hline Denmark & 0.127 & 23 & 0.099 & 26 & 0.086 & 26 & -0.042 \\
\hline Netherlands & 0.072 & 27 & 0.065 & 28 & 0.063 & 27 & -0.009 \\
\hline Croatia & n.a. & n.a. & 0.283 & 14 & n.a. & n.a. & n.a. \\
\hline Average & 0.298 & & 0.317 & & 0.305 & & 0.007 \\
\hline Median & 0.243 & & 0.280 & & 0.274 & & 0.031 \\
\hline Maximum & 0.882 & & 0.912 & & 0.890 & & 0.008 \\
\hline Minimum & 0.072 & & 0.065 & & 0.063 & & -0.009 \\
\hline
\end{tabular}

Source: calculated and compiled by authors based on (Eurostat, 2019) 
Table 2 indicates the leadership of Latvia (0.376), Lithuania (0.354), and Austria (0.345 in 2013) by female-to-male ratios considering utilized agricultural area (ha) under supervision in EU member-states in 2005-2013, while outsiders were Malta, Denmark, and Netherlands. The average, maximum and minimum values of the ratio declined by $0.003,0.098$, and 0.017 respectively; only median increased from 0.126 to 0.142 during the observed period.

Table 2. Dynamics of female-to-male ratio of managers considering utilized agricultural area (ha) under supervision in EU member-states in 2005-2013

\begin{tabular}{|c|c|c|c|c|c|c|c|}
\hline \multirow{2}{*}{ Country } & \multicolumn{2}{|c|}{2005} & \multicolumn{2}{|c|}{2010} & \multicolumn{2}{|c|}{2013} & \multirow{2}{*}{ Change } \\
\hline & Score & Rank & Score & Rank & Score & Rank & \\
\hline Latvia & 0.474 & 1 & 0.428 & 1 & 0.376 & 1 & -0.098 \\
\hline Lithuania & 0.403 & 2 & 0.382 & 2 & 0.354 & 2 & -0.049 \\
\hline Austria & 0.296 & 3 & 0.361 & 3 & 0.345 & 3 & 0.049 \\
\hline Italy & 0.215 & 6 & 0.260 & 4 & 0.259 & 4 & 0.044 \\
\hline Romania & 0.237 & 4 & 0.222 & 6 & 0.224 & 5 & -0.013 \\
\hline Poland & 0.184 & 9 & 0.208 & 8 & 0.205 & 6 & 0.021 \\
\hline Slovenia & 0.232 & 5 & 0.247 & 5 & 0.192 & 7 & -0.040 \\
\hline Portugal & 0.161 & 10 & 0.195 & 9 & 0.186 & 8 & 0.025 \\
\hline Spain & 0.144 & 12 & 0.168 & 11 & 0.176 & 9 & 0.032 \\
\hline Hungary & 0.100 & 17 & 0.132 & 15 & 0.160 & 10 & 0.060 \\
\hline Estonia & 0.200 & 7 & 0.168 & 10 & 0.155 & 11 & -0.045 \\
\hline France & 0.152 & 11 & 0.156 & 12 & 0.152 & 12 & 0.000 \\
\hline Bulgaria & 0.134 & 13 & 0.138 & 14 & 0.147 & 13 & 0.013 \\
\hline Greece & 0.196 & 8 & 0.142 & 13 & 0.142 & 14 & -0.054 \\
\hline Luxembourg & 0.082 & 20 & 0.129 & 16 & 0.126 & 15 & 0.044 \\
\hline Belgium & 0.112 & 15 & 0.115 & 17 & 0.120 & 16 & 0.008 \\
\hline Slovakia & 0.088 & 18 & 0.092 & 19 & 0.097 & 17 & 0.009 \\
\hline Cyprus & 0.126 & 14 & 0.106 & 18 & 0.095 & 18 & -0.032 \\
\hline Sweden & 0.067 & 23 & 0.082 & 21 & 0.082 & 19 & 0.014 \\
\hline Ireland & 0.102 & 16 & 0.087 & 20 & 0.080 & 20 & -0.022 \\
\hline Germany & 0.064 & 24 & 0.070 & 24 & 0.072 & 21 & 0.009 \\
\hline United Kingdom & 0.077 & 22 & 0.067 & 26 & 0.072 & 22 & -0.005 \\
\hline Finland & 0.079 & 21 & 0.079 & 22 & 0.070 & 23 & -0.009 \\
\hline Czech Republic & 0.056 & 25 & 0.068 & 25 & 0.067 & 24 & 0.011 \\
\hline Malta & 0.051 & 26 & 0.077 & 23 & 0.057 & 25 & 0.006 \\
\hline Denmark & 0.088 & 19 & 0.049 & 27 & 0.039 & 26 & -0.049 \\
\hline Netherlands & 0.047 & 27 & 0.031 & 28 & 0.030 & 27 & -0.017 \\
\hline Croatia & n.a. & n.a. & 0.209 & 7 & n.a. & n.a. & n.a. \\
\hline Average & 0.154 & & 0.160 & & 0.151 & & -0.003 \\
\hline Median & 0.126 & & 0.135 & & 0.142 & & 0.016 \\
\hline Maximum & 0.474 & & 0.428 & & 0.376 & & -0.098 \\
\hline Minimum & 0.047 & & 0.031 & & 0.030 & & -0.017 \\
\hline
\end{tabular}

Source: calculated and compiled by authors based on (Eurostat, 2019) 
Considering labor force directly employed by the holdings in EU member-states in 2005-2013, Latvia (0.685), Lithuania (0.610), and Austria (0.469) were at the top of the ranking, while Malta, Denmark, and Netherlands - at the bottom (Table 3). The average and median values of the indicators grew by 0.008 and 0.040 respectively, while maximum fell from 0.715 to 0.685 , and minimum - from 0.052 to 0.040 .

Table 3. Dynamics of female-to-male ratio of managers considering labor force directly employed by the holdings in EU member-states in 2005-2013

\begin{tabular}{|c|c|c|c|c|c|c|c|}
\hline \multirow{2}{*}{ Country } & \multicolumn{2}{|c|}{2005} & \multicolumn{2}{|c|}{2010} & \multicolumn{2}{|c|}{2013} & \multirow{2}{*}{ Change } \\
\hline & Score & Rank & Score & Rank & Score & Rank & \\
\hline Latvia & 0.715 & 1 & 0.716 & 1 & 0.685 & 1 & -0.030 \\
\hline Lithuania & 0.560 & 2 & 0.618 & 2 & 0.610 & 2 & 0.050 \\
\hline Austria & 0.463 & 3 & 0.530 & 3 & 0.469 & 3 & 0.006 \\
\hline Portugal & 0.289 & 8 & 0.385 & 4 & 0.369 & 4 & 0.079 \\
\hline Poland & 0.314 & 5 & 0.335 & 5 & 0.354 & 5 & 0.041 \\
\hline Romania & 0.278 & 9 & 0.298 & 9 & 0.321 & 6 & 0.043 \\
\hline Italy & 0.291 & 7 & 0.305 & 8 & 0.290 & 7 & -0.001 \\
\hline Bulgaria & 0.177 & 14 & 0.271 & 10 & 0.276 & 8 & 0.099 \\
\hline Estonia & 0.372 & 4 & 0.332 & 7 & 0.274 & 9 & -0.097 \\
\hline Slovenia & 0.304 & 6 & 0.333 & 6 & 0.259 & 10 & -0.046 \\
\hline Greece & 0.220 & 10 & 0.257 & 11 & 0.255 & 11 & 0.036 \\
\hline Spain & 0.209 & 11 & 0.233 & 13 & 0.240 & 12 & 0.031 \\
\hline Hungary & 0.191 & 13 & 0.229 & 14 & 0.238 & 13 & 0.047 \\
\hline France & 0.206 & 12 & 0.219 & 15 & 0.217 & 14 & 0.011 \\
\hline Luxembourg & 0.121 & 21 & 0.164 & 16 & 0.181 & 15 & 0.060 \\
\hline Cyprus & 0.171 & 15 & 0.155 & 17 & 0.148 & 16 & -0.023 \\
\hline Sweden & 0.117 & 22 & 0.139 & 18 & 0.145 & 17 & 0.029 \\
\hline Belgium & 0.132 & 18 & 0.137 & 19 & 0.138 & 18 & 0.006 \\
\hline United Kingdom & 0.127 & 20 & 0.095 & 23 & 0.117 & 19 & -0.011 \\
\hline Slovakia & 0.137 & 17 & 0.110 & 22 & 0.113 & 20 & -0.024 \\
\hline Finland & 0.128 & 19 & 0.124 & 20 & 0.111 & 21 & -0.017 \\
\hline Ireland & 0.144 & 16 & 0.119 & 21 & 0.106 & 22 & -0.038 \\
\hline Germany & 0.080 & 24 & 0.084 & 25 & 0.087 & 23 & 0.006 \\
\hline Czech Republic & 0.078 & 25 & 0.085 & 24 & 0.078 & 24 & -0.001 \\
\hline Malta & 0.052 & 27 & 0.082 & 26 & 0.065 & 25 & 0.013 \\
\hline Denmark & 0.095 & 23 & 0.071 & 27 & 0.060 & 26 & -0.035 \\
\hline Netherlands & 0.054 & 26 & 0.043 & 28 & 0.040 & 27 & -0.015 \\
\hline Croatia & n.a. & n.a. & 0.255 & 12 & n.a. & n.a. & n.a. \\
\hline Average & 0.223 & & 0.240 & & 0.231 & & 0.008 \\
\hline Median & 0.177 & & 0.224 & & 0.217 & & 0.040 \\
\hline Maximum & 0.715 & & 0.716 & & 0.685 & & -0.030 \\
\hline Minimum & 0.052 & & 0.043 & & 0.040 & & -0.012 \\
\hline
\end{tabular}

Source: calculated and compiled by authors based on (Eurostat, 2019)

The results showed the leading positions of Baltic countires, probably, due to their openness to new innovative ideas of female empowerment, especially after 
freeing from the communist burden, and lack of traditional managerial structure determining the patterns and trends in other EU member-states (i.e., Germany, Denmark, and Netherlands). Our assumption requires further inter-disciplinary researches that rely on quantitative and qualitative methods including questionnaires and interviews of female and male managers in EU rural business.

\section{Concusions}

1. We can assume that female-to-male ratios of managers considering number of agricultural holdings, utilized agricultural area, and labor force directly employed by the holdings in EU member-states in 2005-2013 demonstrated the absence of gender parity. Therefore, EU member-states should introduce special measures, such as information campaigns aimed particularly at females attracting them to apply for managerial positions in agriculture, gender quotas, training programs and mentorship aimed at bridging the gender gap in rural business management.

2. The statistical provision requires amendments, as the latest available data is 2013, while there was no information regarding Croatia in 2005 and 2013. The enhanced statistical support will guarantee the monitoring of efficiency of national and supranational programs devoted to female empowerment in EU agriculture in general and in managerial decision-making in particular.

\section{References}

Agarwal, B. (2018) Gender Equality, Food Security and the Sustainable Development Goals // Current Opinion in Environmental Sustainability 34, 26-32

Akter, S., Rutsaert, P., Luis, J., Htwe, N.M., San, S.S., Raharjo, B., Pustika, A. (2017) Women's empowerment and gender equity in agriculture: A different perspective from Southeast Asia // Food Policy 69, 270-279.

Alkire, S., Meinzen-Dick, R., Peterman, A., Quisumbing, A., Seymour, G., Vaz, A. (2013) The Women's Empowerment in Agriculture Index // World Development 52, 71-91.

Campos, A.P., Covarrubias, K.A., Patron, A.P. (2016) How does the Choice of the Gender Indicator Affect the Analysis of Gender Differences in Agricultural Productivity? Evidence from Uganda // World Development 77, 17-33.

Doss, C., Meinzen-Dick, R., Quisumbing, A., Theis, S. (2018) Women in agriculture: Four myths // Global Food Security 16, 69-74.

Drucza, K., Peveri, V. (2018) Literature on Gendered Agriculture in Pakistan: Neglect of Women's Contributions // Women's Studies International Forum 69, 180-189.

Eurostat (2019) Agricultural training of farm managers: number of farms, agricultural area, labour force and standard output (SO) by age and sex of the manager http://appsso.eurostat.ec.europa.eu/nui/show.do?dataset=ef_mptrainman\&lang=en [20 05 2019].

Fischer, G., Wittich, S., Malima, G., Sikumba, G., Lukuyu, B., Ngunga, D., Rugalabam, J. (2018) Gender and mechanization: Exploring the sustainability of mechanized forage chopping in Tanzania // Journal of Rural Studies 64, 112-122.

Holt-Gimenez, E. (2008) The World Food Crisis: What's Behind It and What We Can Do // Hunger Notes, 23.10.2008. -http://www.worldhunger.org/world-food-crisis [20 05 2019]. 
Johnson, L.B., Schnakenberg, G. (2017) Gendering strategies for civic agriculture: The case of Blue Ridge Women in agriculture and the High Country Farm Tour // Journal of Rural Studies 55, 181-192.

Johnson, N.L., Kovarik, C., Meinzen-Dick, R., Njuki, J., Quisumbing, A. (2016) Gender, Assets, and Agricultural Development: Lessons from Eight Projects // World Development 83, 295311.

Lukianenko, D.G., Poruchnyk, A.M., Stoliarchuk, Y.M. (2014) International Economics. Kyiv, KNEU.

Mekonnen, D.A., Gerber, N., Matz, J.A. (2018) Gendered Social Networks, Agricultural Innovations, and Farm Productivity in Ethiopia // World Development 105, 321-335.

Mutenje, M.J., Farnworth, C.R., Stirling, C., Thierfelder, C., Mupangwa, W., Nyagumbo, I. (2019) A cost-benefit analysis of climate-smart agriculture options in Southern Africa: Balancing gender and technology // Ecological Economics 163, 126-137.

Osabuohiena, E.S., Efobic, U.R., Herrmann, R.T., Gitaud, C.M.W. (2019) Female Labor Outcomes and Large-scale Agricultural Land Investments: Macro-micro Evidence from Tanzania // Land Use Policy 82, 716-728.

Palacios-Lopez, A., Christiaensen, L., Kilic, T. (2017) How much of the labor in African agriculture is provided by women? // Food Policy 67, 52-63.

Ragsdale, K., Read-Wahidi, M.R., Wei, T., Martey, E., Goldsmith, P. (2018) Using the WEAI+ to explore gender equity and agricultural empowerment: Baseline evidence among men and women smallholder farmers in Ghana's Northern Region // Journal of Rural Studies 64, 123-134.

Sraboni, E., Quisumbing, A. (2018) Women's empowerment in agriculture and dietary quality across the life course: Evidence from Bangladesh // Food Policy 81, 21-36.

Theriault, V., Smale, M., Haider, H. (2017) How Does Gender Affect Sustainable Intensification of Cereal Production in the West African Sahel? Evidence from Burkina Faso // World Development 92, 177-191.

World Economic Forum (2019) The Global Gender Gap Report 2018https://www.weforum.org/reports/the-global-gender-gap-report-2018 [20 05 2019].

Zirham, M., Palomba, R. (2016) Female agriculture in the short food supply chain: a new path towards the sustainability empowerment // Agriculture and Agricultural Science Procedia 8, 372377.

\title{
LYČIŲ LYGYBĖS STATIKA ES KAIMO VERSLŲ VADYBOJE
}

\author{
Lesya Kolinets', Volodymyr Tokar ${ }^{2, *}$ \\ ${ }^{1}$ Ternopilio nacionalinis ekonomikos universitetas, Ukraina \\ ${ }^{2}$ Kijevo nacionalinis ekonomikos universitetas, Ukraina
}

Gauta 201907 19; priimta 20190902

Straipsnio aktualumas susijęs su Jungtinių Tautų organizacijos paskelbtų ir ES ịstatymų leidybos bei praktikoje įtvirtintų darnaus vystymosi tikslų igyvendinimu, t.y. lyčiu lygybès užtikrinimu stiprinant žemès ūkio gamybą. Pagrindinė tyrimų problema yra lyčių lygybės „,status quo" nustatymas ES kaimo verslo vadyboje. Straipsnio tikslas - įvertinti moterų ir vyrų santykị tarp ES valstybių narių žemès ūkio valdų valdytojų. Straipsnio tikslai yra nustatyti pirmaujančias šalis, taip pat siūlyti rekomendacijas, kaip pakeisti situaciją. Tyrimo rezultatai parode lyderiaujančias Baltijos šalių pozicijas 
tikriausiai dèl jų atvirumo naujoms inovatyvioms moterų igalinimo idëjoms, ypač išsilaisvinus nuo komunistinès naštos, taip pat dèl tradicinès vadybos struktūros, lemiančios kitų ES valstybių narių modelius (t.y. Vokietijos, Danijos ir Nyderlandų). Specialios priemonès, skirtos ịveikti nustatytą lyčių lygybès nebuvimą, turètų apimti informavimo kampanijas, kuriomis reklamuojamos vadovaujančios pareigos žemès ūkyje moterims, lyčių lygybės principai siekiant panaikinti lyčių atotrūkị kaimo verslo valdyme.

Raktiniai žodžiai: žemès ūkio vadovai, lyčiu lygybè, kaimo verslas, tvarios plètros tikslai, ES valstybès narès.

JEL kodai: J16, Q13. 